\title{
Availability of Cariogenic Foods in Primary School Canteens of Abha City, Saudi Arabia: A Cross-Sectional Study
}

Rafi A Togoo, Zakirulla Meer, Reena Kandlaya, Syed Mohammed Yaseen

Turki Dhafer Al-Shehri, Hatim Ghormallah Al-Ghamdi

\begin{abstract}
Objective: To obtain base line data about the availability of cariogenic foods in the primary school canteens in the city of Abha, Saudi Arabia.

Materials and methods: The present study was performed in 6 to 10-year-old school boys living in Abha city in 2012. Eight public primary schools with canteen facilities were randomly selected and all the children in the schools were included in the study. Data was collected to know the availability of foods which are cariogenic and the students were made to answer a questionnaire that had questions about their source of food intake.
\end{abstract}

Results: A total number of 1,807 primary school students participated in the study. $87 \%$ of the items available in school canteens were cariogenic and only $13 \%$ were noncariogenic. 1505 $(83 \%)$ school children get food from home, 263 (15\%) depend entirely on the canteen, $1320(73 \%)$ eat from both home and canteen and only $158(8 \%)$ of the school children rely entirely on homemade food.

Conclusion: The canteens should reinforce the classroom programs relating to food, nutrition and health. Standard guidelines have to be implemented throughout Saudi Arabia about eating habits in school and improve the overall nutritional quality of school food.

Keywords: Dental caries, Cariogenic foods, School canteens. How to cite this article: Togoo RA, Meer Z, Kandlaya R, Yaseen SM, Al-S hehri TD, Al-G hamdi HG. Availability of Cariogenic F oods in Primary School C anteens of Abha City, Saudi Arabia: A CrossSectional Study. World J Dent 2012;3(3):239-242.

\section{Source of support: Nil}

Conflict of interest: None declared

\section{INTRODUCTION}

The K ingdom of Saudi A rabia has undergonea rapid change in its socioeconomic situation, food consumption patterns, life style and health status during the past four decades. Communicable diseases have almost diminished and dietrelated chronic diseases have become the major health problems. ${ }^{1}$ Dental caries (DC) is a major public health problem among primary school children in the kingdom, ${ }^{2-7}$ and since last decade, the prevalence has risen dramatically from $68^{2}$ to $96 \%{ }^{7}$ DC is a multifactorial microbial disease in which diet plays a significant role. There has been an enormous amount of experimental research published worldwide, linking fermentable carbohydrate (sugar) with DC. A kpata et al ${ }^{8}$ in 1992, found a significant relationship between decayed and filled surfaces of teeth and the frequency of sugar consumption in 12 to 13-year-old Saudi children.
Food preferences are established early in life and are learned through experiences with food and eating. ${ }^{9,10} \mathrm{~K}$ ey factors in the development of a child's food preferences and eating behaviors are food availability and accessibility. Schools play a major role in influencing the food habits of children as approximately $37 \%$ of a child's total energy intake is consumed at school. Preferences for sweet, energydense foods are well developed by the time children attend school and children will tend to choose these high sugar snack foods, if made available, in preference to more nutritious options. ${ }^{11}$

School nutrition policy is important in supporting children to make positive food choices and therefore schools need to regulate the kind of foods and beverages to be sold in the canteens across the country. The purpose of the present study was to investigate the availability of cariogenic foods in the primary school canteens in the city of A bha, Saudi A rabia.

\section{Subjects and Methods}

The present study was performed in 6 to 10 -year-old school boys living in A bha city in 2012. Eight public primary schools with canteen facilities were randomly selected and all the children in the schools were included in the study. Data was collected to know the availability of foods which are cariogenic and the students were made to answer a questionnaire that had questions about their source of food intake. The data was entered in M icrosoft Excel sheet and descriptive statistics were obtained.

\section{RESULTS}

A total number of 1,807 primary school students participated in the study. Data was collected by two investigators and the foods were categorized as cariogenic and noncariogenic items (Table 1).

A pproximately, $87 \%$ of the items available in the school canteens were cariogenic and only $13 \%$ were noncariogenic (Graph 1).

A questionnaire was filled by the students ( $n=1807$ ) regarding their source of food intake. A round 1505 (83\%) of them replied they bring food from home, 263 (15\%) of them would entirely depend on the canteen, $1320(73 \%)$ of them would eat from both home and canteen and only $158(8 \%)$ of them would rely only on homemade food (Table 2 ). 
Table 1: List of cariogenic and noncariogenic foods in the school canteens

\begin{tabular}{ll}
\hline Cariogenic foods & Noncariogenic foods \\
\hline $\begin{array}{l}\text { Sugar and chocolate } \\
\text { confectionery }\end{array}$ & Bread, sandwiches, toast \\
Cakes and biscuits & Pasta, rice \\
J ams and jellies & Unsweetened/artificially \\
Ice cream & Sweetened yoghurt \\
Fruit syrup & Low-sugar breakfast cereals \\
Sugared soft drinks & Sugar-free confectionery \\
Flavored/sweetened milk & Fresh fruit \\
Buns, pastries, fruit pies & Water \\
Puddings & Sugar-free drinks \\
Sugared breakfast cereals & Milk, cheese \\
& Peanuts and dry fruits \\
& raw/boiled/frozen vegetables \\
& popcorn and fresh corn \\
\hline
\end{tabular}

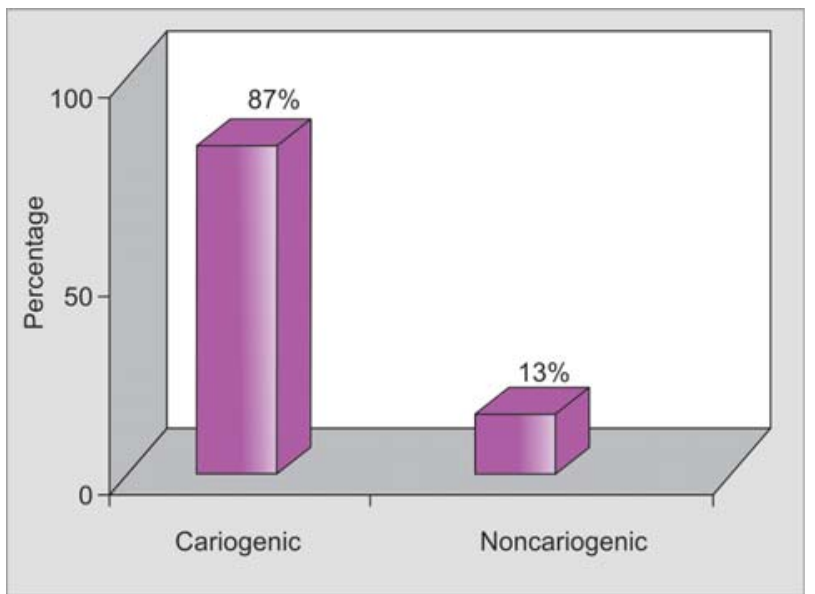

Graph 1: Distribution of cariogenic and noncariogenic items in the school canteen

\section{DISCUSSION}

The present study was undertaken to provide base line data about the availability of cariogenic foods in the primary school canteens in the city of A bha, Saudi A rabia and to identify the percentage of children who consume the foods and beverages from them.

In school canteens, foods most readily available are energy-dense fast foods, carbonated soft drinks, sugary breakfast cereals, salty snacks and baked goods, tend to be high in fats, sugars and salt and nutrient-poor. It is important for health professionals, school authorities and parents to monitor what is being provided to the children in school canteens.

Dental caries is a posteruptive destructive disease of mineralized tissues of the teeth, initiated by acids produced in dental plaque by bacterial fermentation of carbohydrate substrates. A rapid increase in caries probably is because of change to modern diet and dietary habits dominated by products containing refined carbohydrates. A similar trend has also been reported from Canada, ${ }^{12} \mathrm{~A}$ lask ${ }^{13}$ and $\mathrm{A}$ sian countries. $^{14}$

$M$ ajority of the items sold in canteen were cariogenic (87\%). This partly explains the high prevalence of DC in this age group in the country. In socioeconomically developing countries, changing from a traditional to a W estern-style diet has lead to an increase in the consumption of commercialized food products which are high in sugar and fat. ${ }^{15,16}$

In response to the questions regarding the source of food, majority of them were utilizing the school canteen for eating during school hours. Only $8 \%$ of them were completely independent of canteen food. This shows that increasing number of students are relying on school canteens.

The school canteen should provide opportunities to reinforce healthy eating practices and promote sound long-term nutritional habits among the children. On contrary, school canteens in the country have become a consistent source of supply of cariogenic foods. In school canteens, foods most readily available are energy-dense fast foods, carbonated soft drinks, sugary breakfast cereals, salty snacks and baked goods, tend to be high in fats, sugars and salt and nutrient-poor.

It is important for health professionals, school authorities and parents to monitor what is being provided to the children in school canteens. On the basis of the present findings, the authors would like to make some recommendations to promote healthy noncariogenic dietary habits among children.

Table 2: Source of the foods consumed by the children in the school

\begin{tabular}{lccccccccc}
\hline Schools (n)/questions & $1(270)$ & $2(162)$ & $3(177)$ & $4(226)$ & $5(163)$ & $6(345)$ & $7(244)$ & $8(220)$ & Total (1807) \\
\hline $\begin{array}{l}\text { Students bringing } \\
\text { food from home }\end{array}$ & 236 & 133 & 161 & 195 & 128 & 272 & 192 & 188 & $1505(83 \%)$ \\
$\begin{array}{l}\text { Students depending } \\
\text { on the canteen }\end{array}$ & 32 & 37 & 13 & 30 & 28 & 65 & 41 & 17 & $263(15 \%)$ \\
$\begin{array}{l}\text { Students getting } \\
\text { food from home and }\end{array}$ & 216 & 122 & 136 & 167 & 121 & 218 & 162 & 178 & $1320(73 \%)$ \\
$\begin{array}{l}\text { using the school canteen } \\
\begin{array}{l}\text { Students who do not use } \\
\text { the school canteen }\end{array}\end{array}$ & 20 & 8 & 20 & 30 & 14 & 38 & 18 & 10 & $158(8 \%)$ \\
\hline
\end{tabular}


Availability of Cariogenic Foods in Primary School Canteens of Abha City, Saudi Arabia: A Cross-Sectional Study

The dental professionals should be encouraged to create partnerships with parents, school authorities and other dental professionals. They should influence the school authorities to incorporate the oral heal th aspect into the School nutrition Policy and take the responsibility of creating aw areness of the relationship between good oral and good overall health among the parents and children. ${ }^{17}$

The schools should monitor their canteens, offer healthy food and beverage choices, involve and educate teachers and parents about the benefits of high nutrient and low cariogenic snacks, incorporate interactive oral health, nutrition and health education programs in the school curriculum, eliminate marketing of low in nutrition and highly cariogenic food in the school premises. ${ }^{17}$

The parents should cooperate in school dental health programs, avoid replacing proper meals by cariogenic snacks encourage children to have more milk, fruits and noncariogenic foods and monitor what the child eats and drinks at school. ${ }^{17}$

\section{CONCLUSION}

Although the term 'healthy eating' is familiar to children, it is neither well understood nor applied in practice. The canteen should reinforce the classroom programs relating to food, nutrition and health. Both internationally and locally, school-based nutrition programs that include policy, provision of supportive environments and education are recognized as an important strategy in contributing to improved educational and health outcomes. M ore research is needed to demonstrate the best ways to encourage the children to adopt healthier eating practices at school and throughout the day and to counteract pressures from advertising and elsewhere that encourage the consumption of foods high in fat, salt and sugar and that may promote over-eating and weight gain. Standard guidelines have to be implemented throughout Saudi A rabia about eating habits in school and improve the overall nutritional quality of school food. However, changing perceptions of school meals and marketing nutritious foods as an attractive and heal thy lunchtime option continues to be a challenge. Limited research activities investigating the impact of diet and nutrition on health, behavior, and academic achievement highlights the need for continuing research activities to build a robust evidence base that supports the case for change. Nutrition education of parents appears to be important aspect in changing the child's unhealthy food habits.

\section{REFERENCES}

1. A bdulrahman OM, Hamed RT, A bdelmonem SH, Hamza AT. Food-B ased Dietary Guidelines for the Arab Gulf Countries. J ournal of Nutrition and M etabolism 2012;2012:1-10.
2. Al-Sekait MA, AI-Nasser AN. Dental caries prevalence in primary Saudi Schoolchildren in Riyadh District. Saudi M ed J 1988;9:606-09.

3. A I-Shammary A R, Guil EE, El-B uckly M. Prevalence of caries in primary school children in Saudi A rabia. Community Dent Oral Epidemiol 1990;18:320-21.

4. Al-K hateeb TL, AI-M arsafi A I, O'M ullane DM. Caries preval ence and treatment needs amongst children in an $A$ rabian community. Community D ent Oral Epidemiol 1991;19:277-80.

5. Maqbool G. Prevalence of dental caries in school children in Al-K hobar, Saudi A rabia. J D ent Child 1992;59:384-81.

6. Wyne AH, AI-Ghorabi BM, Al-A siri Y A, Khan. NB. Caries prevalence in Saudi primary schoolchildren of Riyadh and their teacher oral health knowledge, attitude and practices. Saudi M ed J 2002;23:77-81.

7. Al-M alik MI, R ehbini Y A. Preval ence of dental caries, severity, and pattern in age 6 to 7-year-old children in a selected community in Saudi A rabia. J Contemp Dent Pract 2006; 7:46-54.

8. A kpata ES, AI Shammary A R, Saeed HI. Dental caries, sugar consumption and restorative dental care in 12 to 13 -year-old children in Riyadh, Saudi Arabia. Community Dent Oral Epidemiol 1992;20:343-46.

9. Dietz W, Gortmaker S. Preventing obesity in children and adolescents. A nn Review of Pub Health 2001;22:337-53.

10. O'Connor T, Y ang S, Nicklas T. Beverage intake among preschool children and its effect on weight status. Pediatrics 2006;118(4):1010-18.

11. B ell AC, Swinburn BA. W hat are the key food groups to target for preventing obesity and improving nutrition in schools? Eur J Clin Nutr 2004;58:258-63.

12. M ayhall JT. Canadian inuit caries experience 1960-1973. J Dent Res 1975;54:1245.

13. Bang $G, K$ ristoffersen $T$. D ental caries and diet in an A laskan Eskimo population. Scand J Dent Res 1972;80(5):440-44.

14. Infirri JS, Barmes DE. Epidemiology of oral diseasedifferences in national problem. Int Dent J 1979;29(3):183-90.

15. Steyn NP, M yburgh NG, N el JH. Evidence to support a foodbased dietary guideline on sugar consumption in South $\mathrm{A}$ frica. Bulletin of the W orld Health Organization 2003;81:599-608.

16. Popkin B M , Horton S, Soow on K, M ahal A, Shuigao J. Trends in diet, nutritional status and diet related non-communicable diseases in China and India: The economic costs of the nutrition transition. N utrition Reviews 2001;59:379-90.

17. Togoo RA. R ole of school canteens in dental decay. Physicians A cademy 2012;6:41-43.

\section{ABOUT THE AUTHORS}

\section{Rafi A Togoo (Corresponding Author)}

A ssociate Professor, Department of Pedodontics, $\mathrm{K}$ ing $\mathrm{K}$ halid University College of Dentistry, PO B ox 3263, A bha-61471, Saudi A rabia, Phone: 966-7-2418046, e-mail: ratogo@ kku.edu.sa

\section{Zakirulla Meer}

Assistant Professor, Department of Pedodontics, King K halid University College of Dentistry, A bha, Saudi A rabia 


\section{Reena Kandlaya}

A ssistant Professor, Department of M axillofacial and Diagnostic Sciences, King Khalid University College of Dentistry A bha, Saudi Arabia

\section{Syed Mohammed Yaseen}

A ssistant Professor, Department of Pedodontics, King Khalid University College of Dentistry, A bha, Saudi A rabia

\section{Turki Dhafer Al-Shehri}

Intern, Department of Preventive Dental Sciences, King K halid University College of D entistry, A bha, Saudi A rabia

\section{Hatim Ghormallah Al-Ghamdi}

Intern, Department of Preventive Dental Sciences, King K halid University College of D entistry, A bha, Saudi A rabia 